\title{
IHTEPB'Ю
}

DOI https://doi.org/10.32848/agrar.innov.2021.8.15

\section{ІНТЕРВ'Ю КАНДИДАТІВ С.-Г. НАУК, СТАРШИХ НАУКОВИХ СПІВРОБІТНИКІВ ВІДДІЛУ СЕЛЕКЦІЇ ІНСТИТУТУ ЗРОШУВАНОГО ЗЕМЛЕРОБСТВА НААН БОРОВИК ВІРИ ТА КЛУБУКА ВІКТОРА}

- Спеціалісти прогнозують, що такі негативні факти, як зміна клімату посилюватимуться в найближчій перспективі, тому що вони пов'язані з антропогенними чинниками. Яке значення сорту в умовах зміни клімату?

- Значення сорту особливо зросло за умови глобального потепління, коли помітно підвищується температура повітря і ґрунту, дуже часто настають тривалі міждощові періоди. Такі погодні явища навіть за умови зрошення спричинюють стресовий стан рослин і різке зниження їх продуктивності, поширення хвороб і шкідників, погіршення якості продукції. Саме тому селекція сої в Інституті зрошуваного землеробства спрямована на створення нових конкурентоздатних сортів.

Основним методом створення сортів сої в Інституті зрошуваного землеробства НААН залишається внутрішньовидова гібридизація 3 подальшим багаторазовим добором. Окрім того, використовується метод природної гібридизації. Внутрішньовидова гібридизація на сучасному етапі селекції в Інституті проводиться дедалі частіше із залученням різних методів схрещування. Пріоритетні напрями роботи із селекції сої спрямовані на вивчення наукових основ і створення сортів сої із підвищеним адаптивним потенціалом насамперед для вирощування на поливних землях півдня України, з оптимізованими морфологічними ознаками і властивостями (високорослістю, багатоквітковістю, стійкістю до вилягання й ураження хворобами, з високим рівнем фотосинтетичної активності листового апарату, адаптивною здатністю, підвищеною фріксацією атмосферного азоту). Це дозволяє підвищити рівень урожайності насіння на 10-15\%, поліпшити його якість та загальне збільшення виробництва білку та олії порівняно з існуючими сортами, ефективно розвивати вітчизняне сільськогосподарське виробництво, що має соціальну та економічну значимість.

Лише за останні п'ять років в Інституті було створено чотири нових сорти сої для умов зрошення, які відрізняються високою врожайністю, стійкістю до хвороб, адаптованістю до змін клімату. Це скоростиглий сорт сої Монарх, середньоранні сорти Софія, Аратта, середньостиглий - Святогор, які ми рекомендуємо виробникам до впровадження.

Потенційна врожайність скоростиглого (95-105 діб період дозрівання) сорту Монарх становить 4,2 т/га, висота рослин 80-90 см. Сорт технологічний: прикріплення нижнього бобу - 12-14 см. Кущ стиснутий, компактний, має коротке міжвузля, у вузлі 6-10 бобів. Характеризується підвищеною адаптаційною здатністю, стійкий до вилягання, посухи, розтріскування бобів, ура- ження хворобами. У насінні міститься 38,0-40,0\% білка та 21,0-22,0\% олії. Сорт занесений до Державного реєстру сортів рослин України з 2016 року та рекомендований для вирощування на зерно в зоні Лісостепу, Степу, Полісся.

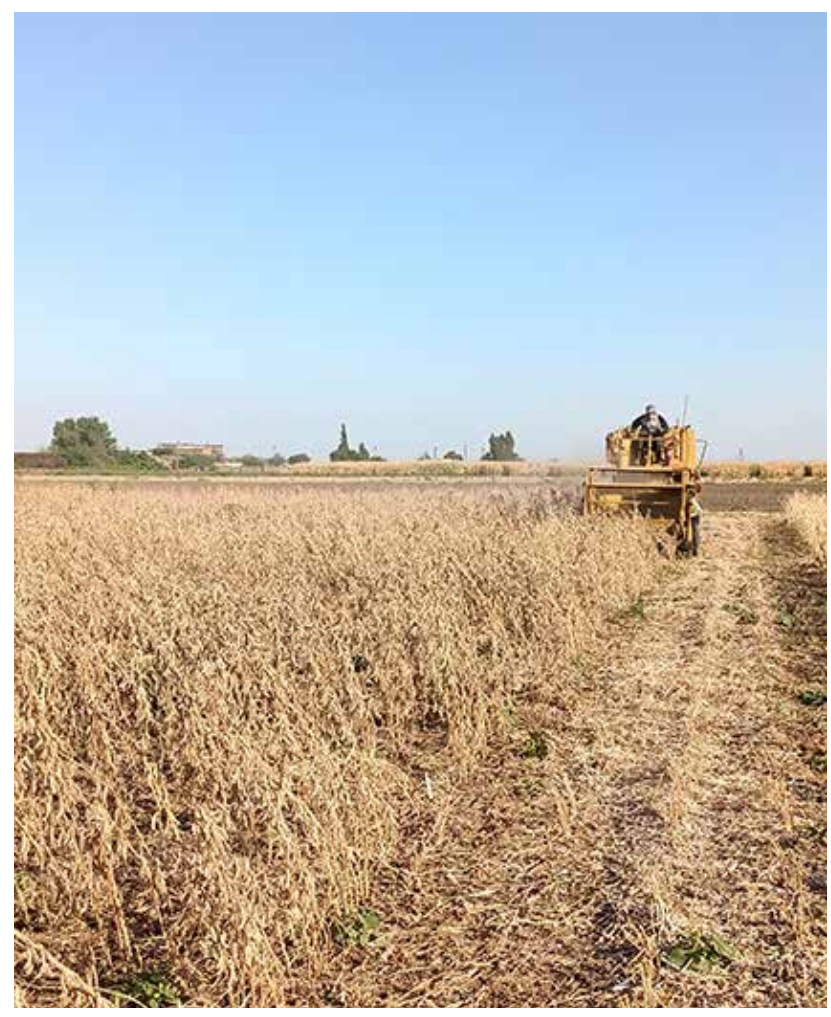

Сорт Софрія $€$ середньораннім (105-115 діб). Потенційна врожайність - 4,5 т/га. Характеризується підвищеною азотфіксуючою здатністю. За сприятливих умов за сезон може накопичити у ґрунті 160-170 кг/га біологічного азоту. Стійкий до вилягання, посухи, розтріскування бобів, ураження хворобами. У насінні міститься $38,0-40,0 \%$ білка та 20,0-21,0\% олії. Рекомендований для вирощування на зерно в зоні Степу.

Сорт сої Аратта середньоранній (105-115 діб). Потенційна врожайність - до 4,2 т/га. У насінні міститься $37,8-39,6 \%$ білка та 20,4-21,8\% олії. Сорт занесений до Державного реєстру сортів рослин України з 2013 року та рекомендований для вирощування в зонах Степу та Лісостепу.

Сорт Святогор є середньостиглим, дозріває за 120-125 діб. Потенційна врожайність становить 6,4 т/га. Стійкий до вилягання, посухи, розтріскування 
бобів та ураження хворобами. Має велике насіння. У насінні міститься 39,0-40,0\% білка та 20,0-22,0\% олії. Рекомендований для вирощування на насіння в зоні Степу.

Сорти сої, створені в Інституті зрошуваного землеробства НААН методом гібридизації, не $є$ геномодифікованими, вони придатні для вживання в їжу як людиною, так і для згодовування тваринам.

- Відомо, що соя може сама накопичувати біологічний азот у ґрунті. Чи необхідно в такому випадку застосовувати добрива?

- Існують суперечливі думки щодо доцільності застосування азотних добрив за вирощування сої. На думку низки науковців, рослини сої повністю забезпечують себе азотом шляхом азотфіксації, тому внесення добрив недоцільно, оскільки останні гальмують цей процес. Утім, інші дослідники рекомендують внесення мінерального азоту під передпосівну культивацію. За такої схеми вирощування спостерігається певне уповільнення процесів азотфіксації, проте не безповоротно - після використання рослиною мінерального азоту процес азотфіксації відновлюється, що врешті-решт позитивно позначається на врожаї.

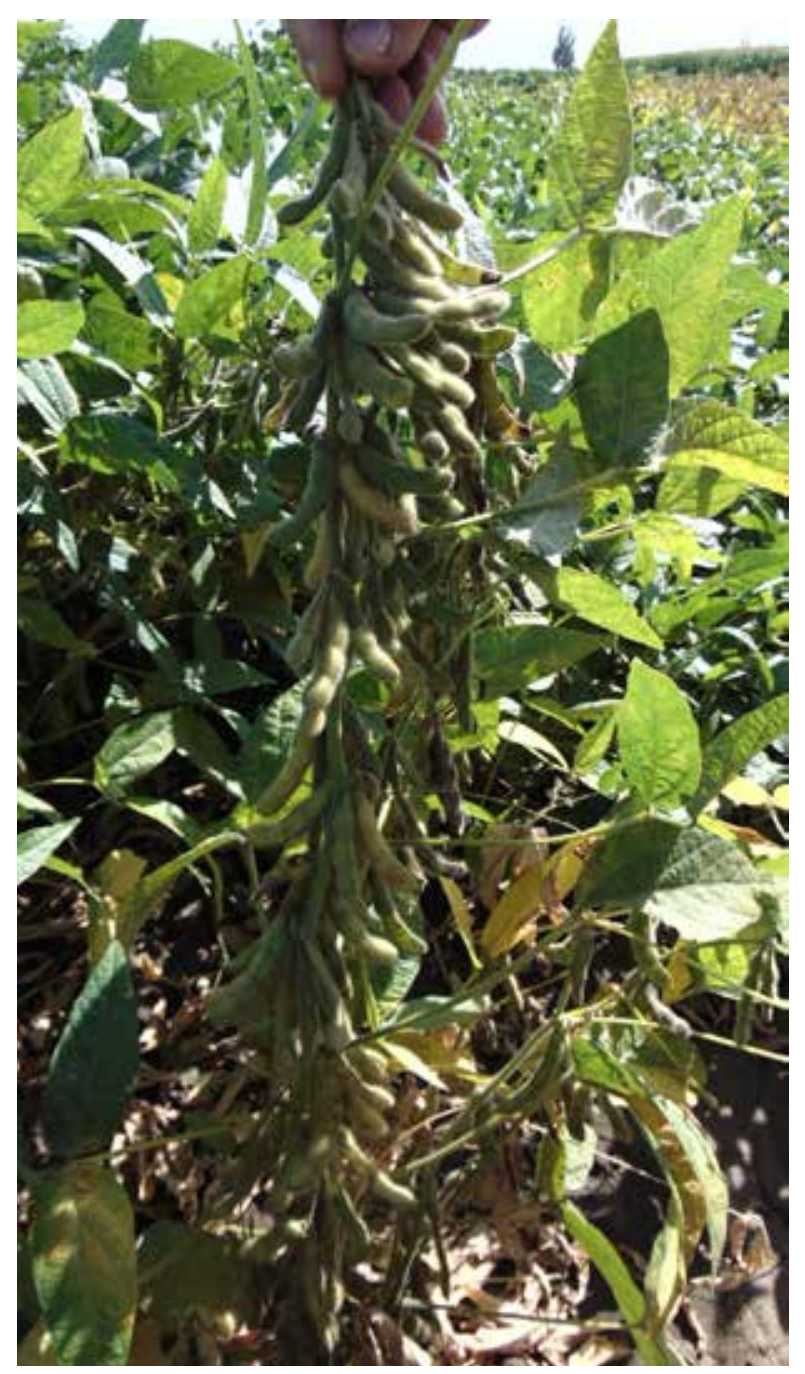

Добре відомо, що завдяки азотфіксації, яка проходить у сформованому симбіозі з ризобіями у бульбах, соя може значно задовольняти свою потребу в азоті (симбіотрофне харчування азотом), що знижує залежність рослин від наявності високих доз азотних сполук у недешевих та екологічно небезпечних азотних добривах.

Водночас одним із важливих зовнішніх фракторів, які впливають на формування і розвиток бульбочок на коренях сої та їхню азотфріксуючу активність, є мінеральний азот. Нашими дослідженнями встановлено, що в умовах півдня України на темно-каштанових середньосуглинкових ґрунтах уміст розчинних азотовмісних сполук у середовищі в польових умовах не перешкоджає роботі бульбочкових бактерій. Зниження частки атмосферного азоту, засвоюваного рослинами за підвищеної забезпеченості мінеральним азотом $\mathrm{N}_{60}$, має тільки відносний характер. Абсолютна кількість азоту, засвоєного бактеріями 3 атмосфери, збільшується порівняно з рослинами, що вирощуються у присутності бульбочкових бактерій, але без внесення у ґрунт азоту. Це пояснюється тим, що азотні добрива не можуть замінити інокулянти, оскільки вони діють на рослину по-різному. Мінеральний азот засвоюється переважно у першій половині вегетації. У період цвітіння і наливу насіння, коли соя вимагає великої кількості цього елементу, інокульовані рослини мають суттєву перевагу над рослинами, підгодованими мінеральним азотом. Перевагою фріксованого азоту, який надходить унаслідок симбіозу рослин і ризобактерій, $є$ рівномірне постачання ним рослин сої протягом усього періоду вегетації, особливо під час цвітіння і наливу бобів. Підвищення норми азотного добрива з $\mathrm{N}_{30}$ до $\mathrm{N}_{60}$ у польових умовах істотно не впливало на симбіотичний процес, але спостерігалася тенденція до меншого накопичення як бульб на рослині, так і їхньої маси.

Максимальна маса бульбочок (0,36 г), що дорівнює 216 кг/га азоту, зафіксована у варіанті з внесенням $\mathrm{N}_{30}$, що дозволяє зробити істотний внесок біологічного азоту в азотне живлення сортів сої, зменшити витрати на внесення мінеральних азотних добрив, здешевити вартість білка, поліпшити екологію навколишнього середовища. Стимулювати процес азотфіксації і водночас збільшити врожайність рекомендується шляхом оброблення насіння рослин сої перед посівом препаратами бульбочкових бактерій - штамами нітрагіну.

\section{- У такому випадку чи варто застосовувати} мікродобрива на посівах сої?

- Дози і співвідношення мінеральних добрив необхідно визначати, виходячи з наявності поживних речовин у ґрунті. Мінеральні добрива, що вносяться у ґрунт, не завжди здатні задовольнити потреби рослини в поживних речовинах. Зміна клімату, збільшення площі вирощування культур інтенсивного типу, дисбаланс заходів із підтримки родючості ґрунтів і складна екологічна ситуація знижують рівень засвоюваності елементів із ґрунту. 3 метою сприяння збалансованого харчування рослин необхідним $€$ застосування таких добрив, які б дозво- 
лили повніше реалізувати потенційну продуктивність сучасних нових сортів сої інтенсивного типу за рахунок кращого забезпечення рослин у критичний період елементами мінерального живлення та сприяли би підвищенню активності фотосинтезу та симбіотичної фіксації азоту, позитивному впливу на ґрунт. Мікродобрива вирішують питання нестачі поживних компонентів.

Мікродобриво - це джерело мікроелементів, які рослина не може отримати із ґрунту. У хелатній формі вони надходять в організм шляхом листового оброблення у період вегетації, унаслідок чого зберігається баланс мікро- та макроелементів у клітинах і тканинах, а це значимий фактор для вегетативного росту, фотосинтезу, утворення білків і лігніну, регуляції окислювально-відновних процесів.

Окрім цього, в рослині може виникнути процес антагонізму - протидії двох елементів. Наприклад, надлишок кальцію значно знижує надходження у тканини рослин бору, заліза, цинку, марганцю і міді, а мідь, у свою чергу, не дозволяє засвоюватися молібдену. За допомогою хелатних добрив можна регулювати баланс мікроелементів у клітинах сільськогосподарської культури, управляти процесами, що відбуваються у тканинах.

До складу таких добрив входять мікроелементи, завданням яких $€$ активізація роботи біологічних каталізаторів, отже, прискорення зростання і розвитку рослини. Після оброблення мікродобривами світло, вода й поживні речовини витрачаються більш ефективно, завдяки чому підвищується врожайність культур, а також якісні показники насіння. Одним із таких мікродобрив є 5-й Елемент - комплексний препарат, до складу якого входять елементи, що покращують ріст кореневої системи, проходження процесу фотосинтезу, синтез білку тощо. Доцільно у період утворення та наливання бобів провести позакореневе підживлення одним із багатокомпонентних хелатних добрив (Еколист, Реаком, Акварін, Плантафол, Вуксал, Кристалон, 5-й елемент) або біостимулятором росту Біо-гель, що підвищить інтенсивність фотосинтезу, знизить ураження рослин хворобами та підвищить урожайність насіння сої.

\section{- Які заходи необхідно проводити для боротьби з бур'янами?}

- Низька конкурентна спроможність сої, умови забезпечення вологою є причинами того, що у ії̈ агроценозах формуються сприятливі умови для росту і розвитку бур'янів різних біологічних груп. 3 однорічних бур'янів найчастіше трапляються такі одно- та двосім'ядольні види, як просо куряче, мишій сизий, гірчак шорсткий, лобода біла, галінсога дрібноквіткова, щириця звичайна, ромашка непахуча, а з багаторічних - осоти рожевий і жовтий, пирій повзучий та інші. Соя має слабку конкурентоздатність до них (особливо у перші 40-50 днів вегетації). Присутність у посівах бур'янів, які $є$ значними конкурентами за основні фрактори життя, зменшують гіллястість рослин сої на 22-50\%, облистяність - на 20-44\%, кількість бобів - на 29-50\%, знижуючи врожай на 20-50\% і більше залежно від складу бур'янів, їхнього розвитку, інтенсивності засмічення. Ще більш злісними у цьому сенсі $€$ багаторічні коренепаросткові бур'яни: наявність однієї рослини осоту рожевого

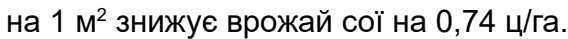

Задля захисту посівів сої від бур'янистих рослин у Південному Степу України застосовуються на практиці зазвичай ґрунтові і страхові гербіциди. Часто в логічних комбінаціях використовуються вони в суміші з додаванням поверхнево активних речовин, ад'ювантів, гуматів, спеціалізованих зернових мікродобрив, карбаміду і сульфрату магнію.

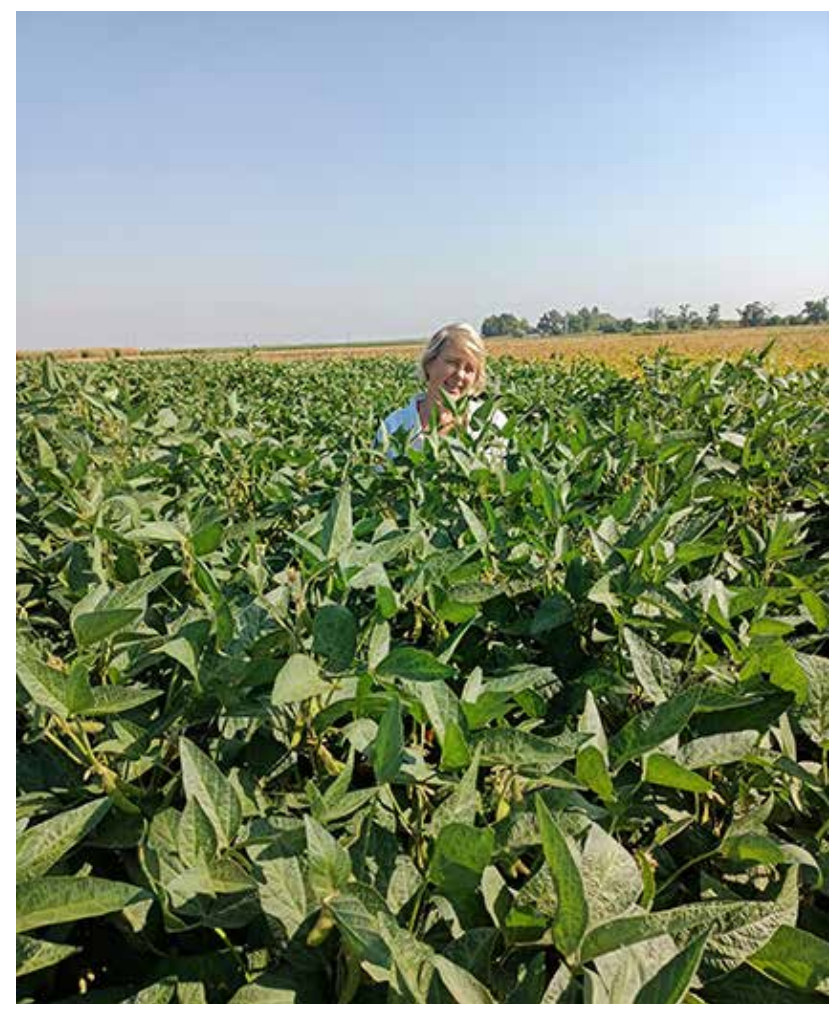

Внесення ґрунтових гербіцидів $€$ обов'язковим під час вирощування сої. За ранніх строків сівби гербіциди можна вносити після посіву сої, за пізніх - надійнішим буде допосівне застосування. Найпоширенішими та ефективними гербіцидами під сою $є$ Фронт'єр Оптіма (1,2-1,4 л/га), Харнес новий 90\% (1,5-3,0 л/га), Дуал голд 960 EC (1,0-1,6 л/га) та інші. Вказані гербіциди використовують переважно для боротьби зі злаковими бур'янами і вносять їх під передпосівну культивацію, або ж до сівби чи після неї (до появи сходів сої) із загортанням у ґрунт боронами. Надалі застосування та вибір страхових гербіцидів визначаються ботанічним складом бур'янів, які залишилися після внесення ґрунтових гербіцидів. Відмінні результати проти бур'янистих рослин показало внесення у 2021 році страхового гербіциду Корум (3,0 л/га).

Не можна забувати про традиційний метод захисту рослин від бур'янів - агротехнічний, який відноситься до фундаментальних методів. Агротехнічними прийомами $\epsilon$ боронування до та після сходів, міжрядні обробки; ефективним $є$ збільшення густоти стояння рослин сої. 
В Інституті зрошуваного землеробства було проаналізовано рівень забур'яненості агрофітоценозу залежно від густоти стояння рослин сої. Науковцями доведено, що цей захід впливає на забур'яненість посівів, зменшуючи кількість бур'янів на одиницю площі: за максимальної норми висіву насіння 900 тис. шт./га підсилювалася конкурентоздатність рослин сої і знижувалася забур'яненість у кількісному значенні на $60,6 \%$, а сира маса на 50,9\%. Отже, збільшення густоти посіву впливало на зменшення забур'яненості посіву на одиницю площі як у кількісному, так і у ваговому відношенні.

Застосування агротехнічного методу сприяє підвищенню ефективності інших заходів захисту, забезпечує їхнє раціональне поєднання з охороною навколишнього середовища. Тому в загальній інтегрованій технології захисту рослин агротехнічний метод $є$ екологічним. Основною підставою для цього є зростаюча загроза забруднення навколишнього середовища пестицидами, до того ж економічно доцільнішим є недопущення масового поширення бур'янів до екологічно небезпечного рівня.

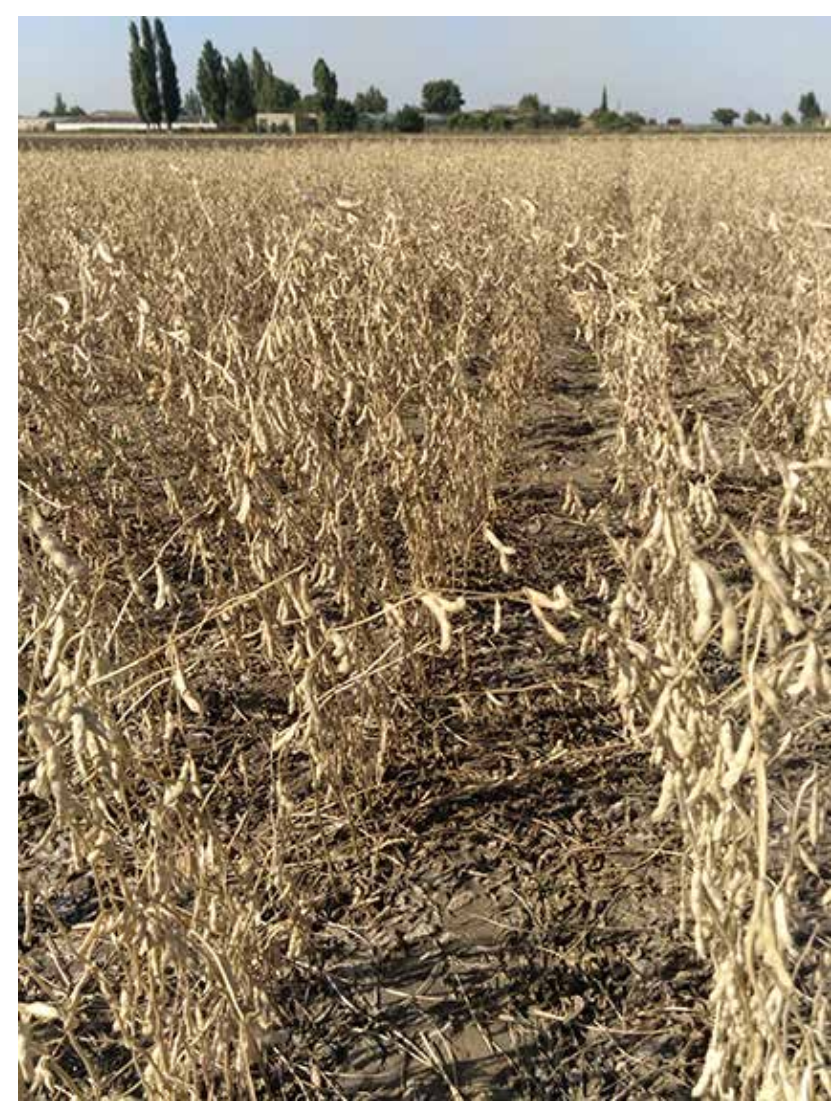

- У чому полягає особливість захисту посівів сої від хвороб у 2021 році?

- На півдні України в сої існує відносно невелика кількість найпоширеніших хвороб, які негативно впливають на врожайність. Проте недооцінювати їх не треба, особливо в умовах 2021 року, коли опади за період вегетації культури в окремих районах становили у травні 97,7 мм, у червні - 89,2 мм.
Науковцями доведено, що серед збудників хвороб найчисельнішою групою представлені гриби. Відносно загальної кількості фрітопатогенів ця група становить $50-100 \%$, ураження бактеріями - 12-28\%, змішана інфекція, тобто ураження бактеріями та грибами одночасно - $14-35 \%$.

На насіннєвому матеріалі сої, а надалі й на вегетуючих рослинах може проявлятися одночасно комплекс хвороб, спричинений декількома патогенами. Для обмеження шкідливості хвороб першочергове значення має контроль ураженості насіння в період зберігання. Тому Інститут зрошуваного землеробства НААН України пропонує виробникам лише сертифіковане здорове насіння сої. Для попередження розвитку хвороб сої у період вегетації важливо пам'ятати, що максимальна ефективність фунгіцидів досягається за їх профрілактичного застосування.

Для захисту від комплексу грибкових хвороб сівбу проводять насінням, обробленим протруйником Максим XL 035 FS т.к.с.(1 л/т) або Февером $(0,2-0,4$ л/т), або Стандак Топом (1-2 л/т). У період вегетації під час боротьби з хворобами і шкідниками застосовують рекомендовані хімічні препарати. Проти хвороб сої слід використовувати Абакус (1,5 л/га) або Коронет (0,7 л/га), або Ретенго (0,5 л/га). Додаючи у бакову суміш Біогель (1,5 л/га), дозу внесення фунгіцидів можна зменшити до $30 \%$. Найпоширенішими шкідниками сої на півдні країни $€$ павутинний кліщ та акацієва вогнівка, проти них використовують акарициди та Бі-58 новий (0,8 л/га) або Золон (2,5 л/га), або Коннект (0,5 л/га), або Белт (0,1 л/га).

У системі біологічного захисту рослин сої можна використовувати на початку цвітіння біофунгіцид Псевдобактерін 2 (2,0 л/га), а на початку формування бобів - біофунгіцид Бактофіт (2,5 л/га) з біоінсектицидом Лепідоцид-БТУ (10,0 л/га).

- Яке значення мають умови зволоження ґрунту у період вегетації сої?

- Визначальним фактором росту й розвитку сільськогосподарських культур у Південному Степу України $\epsilon$ природні умови, що характеризуються сприятливим кліматичним потенціалом, родючими ґрунтами та несприятливим водним режимом. У середні за погодними умовами роки гідротермічний коефіцієнт у цій зоні становить 0,5-0,7, тобто необхідна кількість вологи для формування високих рівнів урожаю сільськогосподарських культур не забезпечується надходженням її із опадами протягом вегетації, що не дає можливості повною мірою реалізувати потенціальну врожайність рослин і значно підвищує ризики ведення землеробства без регулювання умов зволоження.

За вирощування сільськогосподарських культур, зокрема сої, у посушливих умовах Південного Степу України першочерговим завданням $€$ подолання дефіциту природної вологозабезпеченості за рахунок зрошення.

Підвищення врожайності основних сільськогосподарських культур від зрошення може досягати 113,3-220,0\%. Для регулювання умов зволоження грунту в середньому 
за роки проведення досліджень зволоження посівів сої здійснюється шляхом проведення вегетаційних поливів за підтримання передполивної вологості ґрунту у період вегетації на рівні $70 \%$ найменшої вологоємності в розрахунковому шарі ґрунту 0-50 см. Упродовж вегетації рослин сої в умовах півдня України необхідно проводити 7-9 поливів нормою 500 м³/га.

Слід підкреслити, що внаслідок рясних опадів у 2021 році (у травні - 97,7 мм, у червні - 89,2 мм) відпала необхідність проведення першого поливу насінницьких посівів сої в Інституті зрошуваного землеробства НААН.
- Коли рекомендується проводити збір урожаю coï?

- Сою збирають після опадання листя та побуріння бобів за вологості насіння 14-16\%. Спосіб збирання-прямим комбайнуванням зерновими комбайнами з обов'язковим переобладнанням жаток на низький зріз рослин (6-8 см) і зменшенням частоти обертання барабана. Під час збирання сої із вологістю зерна 10-15\% частоту обертання молотильного барабана комбайна регулюють у межах 400-650 об./хв. Обмолочене комбайном зерно очищають від домішок і за необхідності досушують до вологості $14 \%$. 